\title{
Sādhuśabda をめぐつて
}

\section{針 具 邦 生}

sādhuśabda「正しい語」とはパーニニ文典の規定するサンスクリットに他なら ない。インド哲学諸学派にはその標榜する思想の基盤の一つを形成する言語観に 従つて，てれを絶対的なものとして肯定する立場と，逆にその必要性を全く認め ずに否定する立場とがある。前者はサンスクリットを規定する文典の研究に従事 する文典派を筆頭とする正統バラモン系の諸学派であり，後者は仏教・ジャイナ 教等の非正統諸派である。また前者は文典の価値を承認する立場となり，後者は それを否定する立場ともなる。

sādhuśabda，それを規定する文典を学習するととの意義目的は Patañjali (ca. BC. 2c.) の Mahābhāssya の第一日課（Paspaśā Āhnika)1)に詳しく論ぜられたが， その数百年後 (ca. AD. 7c.) の中世インドにおいてての問題は再び批評的に取上 げられた。吾々はその例を正統バラモンの側としてはミーマーンサー学派の Kumārila の Tantravārttika ${ }^{2)}$, 非正統派を代表する仏教の側としては法称（Dharmakīrti) のVādanyāya ${ }^{3)}$ の中に見出すととができる。すなわち Kumārila はそ の Tantravārttika で Mĩmāmsā Sütra (JS.) の聖伝章4) (Smṛtipāda) に摂せら れている論題 9 (JS. I. iii. 24-26)「文法学の論題」に対して Sütra, Bhāsya の 評釈をなすと同時に, Mahābhāsya の Paspaśā Āhnika に対してミーマーンサカ の立場から評釈を加えている。Kumārila の sādhuśabda に対する考えは基本的 に文典派と同一である。かれが上掲の論題で Paspaśā における Kātyāyana, Pa-

1) The Vyākarana-Mahābhāṣya of Patañjali, ed F. Kielhorn, Vol. I, pp. 1-14.

2) Tantravārttika $(T N V)$, Ānandāśrama S. S. No. 97, Poona 1929; Benares S. S. No. 5f, Benares 1882f., TNV のページ, 行は Ānanda. 本によつて示す。

3) Vãdanyāya of Dharmakīrti with the Commentary Vipañcitārthã of Sāntarakșita, The Journal of the Bihar and Orissa Research Society, Vol. XXI Part 4 \& Vol. XXII Part 1, Patna 1935 \& 1936; 西蔵大蔵経北京影印版 No. 5715, Rtsod-pahi rigspa shes-bya-bahi rab-tu byed-pa.

4.) 聖伝章全体の構成については拙稿「タントラ・ヴァールティカ聖伝章和訳咞究(1)」 哲学年報第33輯を参照。 
tañjali よりも考察を深めている点は，特に sādhuśabda の儀礼的な場面での実際 の使用（prayoga）とその結果の関係についてである。との点については別稿5) で 論じたので本稿では立ち入らない。法称はVädanyāya において，Nyāyavrttika の負処 (nigrahasthāna) の第十, 時不到達 (aprāptakāla) の否定論証の過程で sādhuśabda・文法学の無意義であるととについてかなりまとまつた形で論及している。 法称の批判は文典派，特に Bhartrhhari を意識してなされていると考えられる。

本稿では正統バラモン側の sādhuśabda 絶対視の一つの表現としての Kumārila による言葉の正しさ（sādhutva）を criterion とする仏典批判と，その無意味さを 主張する法称の見解を中心にして中世インドにおいて sādhuśabda をめぐつて生 じた正統バラモンと仏教の言語観の相違を指摘しておきたい。

\section{II}

Kumārila は正しい語を浄化された語（samskṛta śabda）と考えそれを祭式行為 を完全にするための必要条件と見，従つて正しい語を規定する文典の聖伝(Smrti) としての権威を認めた。ミーマーンサー学派によれば聖伝は一般に天啓書 (Śruti) に基づくことによつて権威（prāmāṇya) ありとされる6) が，文典も例外ではなく その所依はVeda であるとされている7)。Mahābhāṣya の Paspaśā で述べられ ている様に，正しい語をVeda の規定（niyama）に従つて使用すれば dharma 「功徳」が生じ，それは結果的に abhyudaya「繁栄」をもたらすととを Kumārila も信奉した。サンスクリットが学術用語として専ら使用される背景には，ブ ラフマニズムにおいては Kātyāyana・Patañjali の説く椂なかかる信仰が一般に 定着していたに相違ない8)。またブラフマニズムにあつては，聖典は śabdasatya 「語の真実」をもつて第一とさるべきであり，それに基づいてのみ arthasatya 「意義の真実」もあり得ると考えられていた様である。Kumārila はそれに関連 して次の様に述べている。「あるいは真実性（satyatva）てそがこの sādhutva（と いら語の意味) であり，非真実性（asatyatva）が asādhutva（といら語の意味） であつて，法・非法に関わるものとなる，と表明される。法・非法の確立はそれ

5）「マハーバーシュヤ第一日課とタントラヴァールティカ」哲学年報第34輯。

6）哲学年報第33輯所収拙稿参照。

7）詳細は哲学年報第34輯所収拙稿参照。

8）しかし Kumārila は「文典の意義（prayojana）は何であるかといら点について今 でも文法家達は論争している」という事実があるてとも指摘している。cf. TNV, p. 256. l. 25. 
ぞれ真実と非真実に依存し，それらはそれぞれ（真実は）規定され（非真実は） 禁止されるものであるから聖典の取扱いの対象である。（真実性については）意 義の真実性が主張さるべきであるのと同様に，語の真実性が同様に（主張さるべ きである)。さらに意義の非真実 (arthânṛta) と同様に語の非真実も吾々にとつて は捨てらるべきものである」包と。この Kumärila の主張は「真実を語れ，噓をつ くな。（satyam vaded anṛtam na vadet）」といら倫理的行為を規定する聖典の規定 と禁止について述べられたものであるが，その語らるべき真実は言葉の真実，す なわち言葉の正しさを前提とすべしと説く。それはまた聖典たるととの一つの条 件とも見做されるのである。Kumārila の語の正しさを基準とする仏典批判は一 見的外れで奇妙に思われるが，この様な聖典観より見れば理解されると思われる。

その Kumārila による仏典批判は Tantravārttika の聖伝章 ${ }^{10)}$ 第 7 論題 (JS I. iii. 11-14) に現われる。との論題は本来 Kalpasūtra (-asvataḥprāmāṇya) Adhikaraṇa であり，カルパスートラにはVeda の様な独立の量性がないととを論定す る箇所であるが，Kumārila は Sūtra を様々に解釈して四つの論題を設定し，そ の四番目に仏典批判を置く。その Pūrvapakṣa Sūtra（JS I. iii. 11）は “prayogasāsstramiti cet”であり, Siddhānta Sūtra 1 (JS I. iii. 12) は “na, asanniyamāt” である。Kumārila は Sūtra 11 (Pūrvapakṣa) の下で次の様に述べて仏典批判の 論題を設定する。「あるいは，仏教徒等の聖典が Smṛti 聖典であることはすでに 否定されたから，(仏教が) Veda の学派 (śākhā) に等しいものであるかどらか， といら点が疑われてての箇所でそのことが否定される。何となれば仏教徒等も次 の様に主張しているからである。“utpādādvā tathāgatānām anutpādādvā sthitā eva iyam dharmanityatā”11) (如来がての世に現われても現われなくても，との法の常 住性は安立している。）それゆえに，もしかれらの聖典が Veda の様に常住である と考えられているならば, その（仏教徒によつて）主張された法もVeda の教令

9) $T N V$, p. $276 l l .6-11$.

10） $T N V$ の聖伝章の中に見出される仏典批判は Poussin が “On the Authority of the Buddhist Āgamas” JRAS, 1902 pp. 363-376 に収録して部分的に英訳も示している。

11）「如来出世, 及不出世, 法性常住」雑阿含経, 第三十, 大正蔵第二巻 p. $217 \mathrm{c}$. cf. tathā utpādādvā tathāgatānāmanutpādādvā tathāgātānāṃ sthitâivâiṣā dharmāṇām dharmatā, Prasannapadā, Bibliotheca Buddhica IV, p. 40; 金倉円照博士, 「馬鳴 の研究」p. 139, 注 ( 3 )。

12) ミーマーンサー学派の dharma の定義, “codanālakṣaṇo 'rtho dharmah" (JS I. i. 2). 


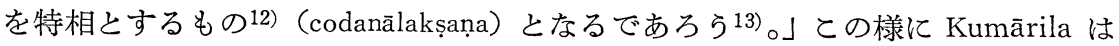
仏典批判の論題を設定し, 仏教の説く「法」の永遠性に関する常套句を引用して 前主張を構成している。

それに対して Kumārila は Siddhānta Sūtra 1 の “asanniyamāt”を六様に解 釈して仏典を批判するが，本稿に関係するのはその中の第二・三の解釈である。 先ず第二の解釈では asat を asādhuśabda, niyama を nibandhana と解釈して次 の様に仏典を批判する。「仏教やジャイナ教等の聖典（āgama）は正しくない言葉 に満ちている。また正しくない言葉で編纂された作品であるから聖典たることは 認められない。すなわちそれらは殆んどマガダ語, 南方の語 (dākṣinātya), その アパブランシャといら正しくない言葉の作品である。(例えば) “mama vihi bhikkhave kammavacca is̄i save/ tathā ukkhite loḍhammi ukkheve atthi kāraṇam paḍane ṇatthi kārạ̣am/ atthy ubbhave kāraṇam ime sakkaḍā dhammā sambhavanti sakāraṇā, akāraṇā viṇasanti aṇupyattikāraṇam"14) 等である。それゆえ， それら真実ではない言葉をもつものに意義の真実性があるのか。あるいはいかに して明らかに語形の損なわれたものに無始性があるのか。」Kumārila は先ずこの 様なプラークリットより成る仏教徒の伝承経典を引用して仏典を批判しているが, さらに仏典の中にはサンスクリットを意図しながらも文典の規則に合致しないも のがあるととを述べて次の様に非難する。「また仏教徒等の著作の中には，知性 の正常な者により sādhuśabda を意図して用いられた語もあるが，その場合でさ

13) $T N V$, p. $230 l l .12-17$.

14）出典不明。cf. Poussin, op, cit., p. 370, note 2; Prasannapada, p. 222 note 5. Prasannapadā pp. 222-3 にはこの Kumārila の引用経典とほぼ一致する偈の経文が 引用されている。“yatha ukkhite loḍhammi ukkheve atthi kāraṇaṃ/ paḍane kāraṇaṃ ṇatthi aṇnam ựkhevakāraṇāt// (p. 222) evime saṃkhatā dhammāḥ saṃbhavanti sakāraṇāh (p. 223)"

15) cf. prajñapti-vijñaptiśabdayor-jānāter-ṆIJ-antatvâbhāve YUG (PUG?)-āgamasya-asādhutvaṃ, ṆIJ-antatve tu "ṇyāsaśrantho yuj (P. III. iii. 107)" iti viśeșavihitena YUC-pratyayena "striyām ktin (P. III, iii. 94)" iti sāmānyavihitasya KTINpratyayasya bādhād-asādhutvam// ŚITi pratyaye prabhūte dṛśeh paśya-ādeśavidhānāt paśyanā-śabdasya-asādhutvam// Nyāyasudhā, Chowkhambā S. S. No. $45 \mathrm{f}$. p. 237, ll. 17-21: paśyatā は Nyāyasudhā では paśyanā となつている。 paśyanā といら形は Edgerton の仏教梵語辞典にはないが, Wackernagel の Altindische Grammatik II-2, S. 204 に仏典の用例として出ている。Poussin は tișthatā を M. A. Barth によつて niștatā と直している。cf. Prasannapadā p. 222, note 5, 
えも殆んど prajñapti, vijñapti, paśyatā, tișțhatā15)等 (の䛊つた語) を用いている から，損なわれていない語は僅かなもののみである。」上が仏典批判において asanniyamāt を asādhuśabda-nibandhanatvāt と解釈する Siddhānta Sūtra 1 の 第二の解釈である。第三の解釈は次の通りである。「人によって作られたもので はない言葉の集合 (=Veda)，損なわれた言葉の集合（＝仏典）、それらを弁別す る一つの手段は文典のみである。またそれによつて弁別された諸の語形は, Veda に認められる様には仏教徒等によつて語られるものの中には認められない。(文 典による) 使用の規則 (prayoga-niyama) が存在しないから，ての理由によつて も仏典には聖典性はない。asanniyamāt とは『文典に述べられた規則が存在しな いから (vyākaraṇôktaniyama-abhāvāt)』といら意味である。」

これらの Kumārila による asanniyamāt の二つの解釈で明膫になるのは, 聖 典は文典の規則に合致した語の正しさを第一条件とする, といら正統バラモンの 聖典観であり，ミーマーンサー学派が主張する「ととばの常住性（śabdanityatva)」 の「ととば」とは「正しいととば（sādhuśabda)」に他ならない16)，というととで ある。との Kumārila の主張の背後には, 文典はある時代の歴史的変遷を経て形 成されてきた言語の構造等を説明解釈するものである，といら様な文典に関する 吾々の一般的常識とは全く異つた文典観がある。Kumārila は sādhuśabda が無 始（anādi）である様に文典も無始であり，文典の権威を保障する「正しい語を用 いるべきである」という Veda の規定 (niyamavidhi) と文典との前後関係は知る ととのできないものである, という見解に立つている17)。Kumārila は以上の様 な聖典観，文典観，言語観に基づいて仏典を批判したのである。

III

法称 (Dharmakīti) が Vãdanyāya の中で直接攻撃したのは Uddyotakara の属 する Nyāya 学派と文典派が承認する sādhuśabda であるが，正統バラモンの奉 ずる言語観の拒否といら形をとるからそれはII で見たミーマーンサー学派の Kumārila による仏典批判への仏教側からの答えにもなつている。

Uddyotakara は Nyāyavārttika (ad Nyāya Sütra V. ii, 11) において, 比量論 式（prayoga）において宗等の支分（avayava）の順序が逆になつたもの一ててれが Nyāya 学派が認め法称は否定する aprāptakāla といわれる負処であるが——を 喻えて「(正しい語の) 使用から外れた語（prayogâpetaśabda）の如し。gauh「牛」

16）とのととについては注（32）の Ślokavārttika の一詩節をも参照。

17） $T N V$, p. $279 l .26$, - p. $280 l .2$, 哲学年報第 34 輯所収拙稿参照。 
といらての語の意味に対して gāvī と（誤つて）使用される語が，背の隆肉等を 有するもの（=牛）といら意味詨象を理解せしめる様なものである」と述べ，さ らに「(文典の目的とする) 語の説明解釈 (anvākhyāna) は無意義ではない。と の（gāvī という䛊つた）語から go という（正しい）語を人は先ず理解し，そ の後 go といら語から背の隆肉等をもつ(「牛」といら）対象を（理解する）」18) と述べて文典の有用性を主張している。ついでに述べるならば，Nyāya 学派は 正統バラモン側に属するから sādhuśabda の意義を認めるが, 文典派やミーマー ンサー学派と異なるのはその起源に関する見解である。Nyāya 学派は語と意味の 定まつた関係を自在神の約束（iśvara-saṃketa）に基づかしめるから， sãdhuśabda もその約束において定められたものであり，さらに Indra, Pāṇini 等は sādhuśabda に関して最も優れて熟達した者であるから，かれらによつて矛盾なく記憶さ れて述べられている語が sādhuśabda である，とする19)。

法称は上の Uddyotakara の主張の排斥を通して文典無用論を説く20)。その主 な理由は次の椂にまとめられる。

(1) 正統バラモン側によつて「誤まれる語（apaśabda, asādhuśabda)」といわれ る語からでも直接け意味を覚知するから，「正しい語（śabda，sādhuśabda）」を知 る手段とされる文典は無用。

(2) 文典による言葉の「浄化（samskāra）」は存在しないから「浄化された語 (samskrta śabda)」なるものも存在しない。

(3) 正しい言葉は dharma を実現する手段である，といらととはない。

との中で(2)と(3)は特に聖語サンスクリットに対する正統バラモン側の信仰に関 わる問題であり，その信仰を受け入れない仏教の立場に立つならばおのずからそ れは否定されざるを光いであろら。従つてとてでは信仰に関わらない(1)の点に ついて法称の見解を見ておきたい。

Uddyotakara の主張からもわかる様に，正統バラモン諸派は，䛊つた語を先ず 正しい語の観念を生ぜしめ，その後にその正しい語が意味対象を表現する（apaśabda $\rightarrow$ sādhuśabda $\rightarrow$ artha)，すなわち apaśabda は間接的にしか意味を表わすもの

18) Nyāyavārttika, Benares 1915, p. 555, l. 22-p. 556, l. 2.

19) cf. Nyāyavārttikatātparyațīkā, Kāśĩ S. S. No. 24, p. 714 ll. 6-9 \& p. 715 ll. 13; Nyāyakośa, 1928 "sādhuh" の項の 2.

20）Vādanyāya p. 103, l. 6-p. 108, l. 3; 乙の部分は Nyāyabhūṣaṇa, Șạ̣darśanaprakāśan-granthamālā No. 1, Benares 1968, pp. 367-368 にも引用がある。 
ではない，と考える21)。

法称はこの見解を次の様に論破する ${ }^{22)}$ 「 「goṇi (or gāvī) といら語からでも世 間においては対象の観念が生ずるのが経験的に知られる。『たしかに経験的に知 られる，しかし直接にではない』23)と主張された。またその主張は正しくない。 なぜなら女性やシュードラ24)にとつては両者を兼ねて知るととはないからである。 (sādhu-) śabda と apaśabda の孰れをも知る人のみがその様に理解するのである。 しかし (「鼻」のことを) nakka とか mukka といら語でしか知らず（Skt.の） nāsā という語を知らない人は, どの様にして apaśabda から (sādhu-) śabda を 理解し，それから意味を理解することができるであろらか。」この様に法称はサ ンスクリットを知らない人の例を挙げて論駁しているが，さらにとのととを一般 化して apaśabda といわれる語もそれが意味を表わす限り約束（samaya）によつ て成立しているものであるてとを主張する。「また（śabda と apaśabda の）両 者を兼ねて知らない人にも（対象の）知が生ずることが経験的に知られるから (apaśabda から) 間接的に（対象の）観念が生ずるといらこともない。意味に 対する（観念を生ずる）能力のないものは（sādhu-） śabda に対する観念をも生 ずる能力はないからである。また意味に対する（sādhuśabda の）能詮性（vācakatva）といら様な別のものはない。なぜなら他（apaśabda）の場合その意味を対 象とする観念を生ずるのであるから。apaśabda がもし（sādhu-）śabda に対する 钼念を生ぜしめ得るとすれば，なぜ意味に対する（観念を）生ぜしめないのか。

21）この主張の Bharț̣hari の表明はVākyapadīya (VP) I-142, Poona 1966 “na śiștairanugamyante paryāyā iva sādhavaḥ/ te yataḥ smṛtiśāstreṇa tasmāt sākṣādavācakaḥ//"「(apaśabda は) 教養人達や（文法の）聖伝書によつて（正しい語の）正 しい同義語である如くには承認されていない。それゆえ直接に意味を詮わすものでは ない。」なお Bhartṛhari の sādhuśabda 観については中村元博士「ととばの形而上 学」pp. 362-370 参照。Kumārila の表明は $T N V$, p. 278, ll. 15-16 “tenânekaprayoge 'pi kaścidevârthasamgatạ̣/ tad upasthāpanenânye (apaśabdāḥ) bodhakāstadaśaktijāh//”和訳は哲学年報第34輯所収拙稿に示している。

22）以下 Vādanyāya, p. 103, l. 10,-p. 105, l. 8. JBORS と Nyāyabhūusana 所引のテ キストとはかなり出入が多いので, Vipañcitärthā と Tibet 訳 (北京版 Bstan-hgyur, Vol. 130, 157-5-4〜158-1-2, チョーネ版 Bstan-hgyur Vol. 96, 345-A-1 345-A-6) を参照しつつ妥当と思われる読みを取つた。なおチョーネ版は伊原教授所蔵のマイク ロフィルムを利用させて頂いた。

23) Skt. satyam dṛștā na tu sākṣādityuktam/ 注（21）におけるVP I-142 の d-pada が念頭にある様である。

24) strīsúüraśabdo mūrkhavacanaḥ, Vipañcitārthā, p. 103, l. 24. 
吾々はその (sãdhuśabda が表わす) 意味と (apaśabda が表わす意味との) 相違を 見ないから，それ（=sādhuśabda のみにありと説かれる能詮性）を否定し得る。また 約束ができていない語には (sādhu-) śabda に対する観念を生起することもない からである。この apaśabda は本性的に (sādhu-) śabda に対する観念を生ずる のではない。その様なととは経験されないから。そうではなく約束 (samaya) か らのみ（対象の観念を）生ぜしめるてとができる。約束を介して apaśabda は sādhuśabda に対して働くのに，(その apaśabda は）意味対象に対してなぜ機能 することがないで方ろうか。かくして（apaśabda は）間接的に観念（を生ずる） といら困難は排斥される。また逆のととが見られるから。(すなわち) (sādhu-) śabda から意味を理解しない人が apaśabda によつて認識を生ずるととが世間で は見られる。それゆえ (文典のおこなう) 言葉の教示 (śabda-anuśāsana)25) は無益 である。」

法称の主張は明暸であろう。しかしそれに対しては正統バラモン側からの反論 が予想される。吾々にとつて重要なのはむしろ sādhuśabda の浄化性といら側面 であり26)，それのみが儀礼を完全にする，それゆ光 sādhuśabda は「法を実現す る手段」27) ともなる，と。しかしての主張は先述した様にブラフマニズムの信仰 に帰せらるべきものであるから，それを信仰しない他派との論争にはなりえない。

法称の sādhuśabda の論駁の中には不正確な形でしか文典派の主張は引用され ていない28)が，攻撃の相手は Bhartṛhari らしく思われることは注に示した通り である。

Vädanyāya に対する寂護（Sāntarakșita）の註釈 (Vipañcitārthā) で特徵的な点 は，正統バラモン側の主張を「正しくない語は sādhuśabda に対する推量を惹き

25) Mahābhāṣya 辟頭 “atha śabdânuśāsanam”.

26）との側面を特に重視するのはミーマーンサー学派。哲学年報第34輯所収拙稿参照。

27）Vādanyāya, p. 106, l. 3 “dharmasādhanatā” この法称の表現は寂護も引用してい る様に, VP I-27 の b-pada “sādhavo dharmasādhanam”を意識している様であ る。

28）その他気付いた引用文では “śabdasya suprayogādeva svargamodanaghoṣan̄ā” (Vādanyāya, p. 106. l. 5) がある。とれの原文は Mahābhāṣya 所引の Śruti “ekah śabdah samyagjñātah suprayuktah svarge loke kāmadhugbhavati” の如し。

29）との考えはVP I-141 の a, b-pada “te sādhuṣvanumänena pratyayôtpattihetavah" にある。cf. Paddhati of Vṛșabhadeva ad VP I-27 “yadyapi sākșādanumānenê ti ca bhedạ̣ tathāpyarthapratyāyanamabhinnam, sādhūnāmasādhūnāṃ ca tulyam" ( $p$. 81, ll. 21-22) 
起す (anumāpaka) ものとなる 」29) と把え, 両者の間に所遍能遍の関係 (vyāpyavyāpakabhāva）が存在しないととを主張することによつて論理的に sādhuśabda を否 定している点である。また法称とは異なり, 寂護は正統バラモン側の文献を正確 に引用している。すなわち文典派のものでは Paspaśā Āhnika30) と Vākyapadī$y a^{31)}$ ，ミーマーンサー学派のものではŚlokavärttika $a^{32)}$ を引用して論駁の対象を 明確にしている点は注目される。Ślokavärttikaの一詩を菽護は Tattvasamgraha (Śrutiparīkṣā) v. 2667 としても引用し，同 v. 2668 では「そらではない，何と なれば漁夫33)等はサンスクリットを知らないからである。根拠となる（正しい） 語に随らととによつて如何して意味の了解が生じえよらか」といら様に法称と同 じ論拠で反論している。

apaśabda は直接には意味対象を表示しない, といら正統バラモン側の主張の 第一点を仏教側が衝いたのは, 以上の様にサンスクリットを知らない人のととを 先ず考慮に入れてのととであつた。Kumārila は「文法学の論題」で長大な前主 張を構成しているにもかかわらずこの点について全く触れることがないのは，仏 教側からの上述の sādhuśabda に対する具体的な反論があるととを知らなかつた のであろら。たとえ仏教側の反論を知らなかつたとしても, その様な反論は容易 に想定可能なととである様に思われる。しかしその反論を予想さえしなかつた所 に, 正統バラモン主義の貴族的もしくは固徆な保守的体質が露顕しているし，逆 に仏教の側は最初にその点を衝いた所に聖語サンスクリットへの信仰をもたず仏 法の伝播のために sādhuśabda という手段を要しないでついに普遍宗教となりえ た仏教の面目がよく現われていると思われる。

(昭和 48 年度文部省科学研究費による研究成果の一部)

30) Vipañcitärthā, p. 106, ll. 14-17.

31）VP I-27, 143，144 引用している。

32) Ślokavārttika, Śabdanityatā Adhikaraṇa v. 276 "gośabde 'vasthite 'smākam tadaśaktijakāritā/ gāvyāder api gobuddhirmūlaśabdā 'nusāriṇi/// 「吾々にとつて go といら語（の永遠性）が確立されている時（世間においては）根拠となる（go と いら）語に随つた gāvĩ 等からでも「牛」の観念が生ずる。それはかれ（発音者）の （go といら正しい語を発音する際の）無能力によつて生ぜしめられたものである。」

33） Skt. śanaka, Vipañcitārthā, p. 103, l. 27 には sanaka とある。「漁夫」の意は辞 書にないが G. Jhā の Tattvasamgraha 英訳（GOS. No. 83, p. 1217）に従つておく。 